\title{
Aktivitas Antifungi Ekstrak Etanol 96\% Rimpang Lempuyang Wangi (Zingiber aromaticum Val.) terhadap Cendawan Pythium sp. secara In Vitro
}

\section{Antifungal Activity of $96 \%$ Ethanol Extract of Zingiber aromaticum Val. Against Pythium sp. under In Vitro Condition}

\author{
Oktira Roka Aji ${ }^{1}$, Hasna Chaerani Zakkiyah ${ }^{1}$ \\ ${ }^{\text {I} P r o g r a m ~ S t u d i ~ B i o l o g i, ~ F a k u l t a s ~ S a i n s ~ d a n ~ T e k n o l o g i ~ T e r a p a n, ~ U n i v e r s i t a s ~ A h m a d ~ D a h l a n ~}$ \\ Jl. Jend. Ahmad Yani (Ringroad Selatan), Tamanan, Banguntapan, Bantul, Yogyakarta \\ Email: oktira.aji@bio.uad.ac.id *Penulis korespondensi
}

\begin{abstract}
Pythium sp. is one of the fungi that causes damping off disease in various plants. Watermelons, cucumbers, and bananas are some examples of plants that are often affected by these fungi. Bitter ginger (Zingiber aromaticum Val.) is a natural source that can be used as a biofungicide because it contains bioactive compounds such as zerumbon, flavonoids, alkaloids, saponins, curcumin, etc, so it is necessary to study their use as an antifungal in plants. Because of that, this research was conducted to assess the optimum concentration of Zingiber aromaticum Val. extract in inhibiting the growth of the fungus Pythium sp. and determine the percentage of optimum anti-fungal activity of the extract of lempuyang wangi (Z. aromaticum Val.). The results showed that the optimum concentration of $Z$. aromaticum Val. extract in inhibiting the growth of Pythium sp. was 50\%. The optimum percentage of antifungal activity from $Z$. aromaticum Val. extract was $51.9725 \%$.
\end{abstract}

Keywords: Bitter Ginger, Zingiber aromaticum Val., Pythium sp., Ethanol Extract, Biofungicide, Antifungal Activity

\begin{abstract}
Abstrak
Pythium sp. menyebabkan penyakit rebah kecambah pada berbagai macam tumbuhan. Semangka, mentimun, dan pisang adalah beberapa contoh tanaman yang sering terkena penyakit rebah kecambah yang disebabkan oleh cendawan tersebut. Lempuyang wangi (Zingiber aromaticum Val.) merupakan bahan alami yang bisa dijadikan sebagai biofungisida karena mengandung zat aktif, yaitu zerumbon, flavonoid, alkaloid, saponin, kurkumin dan lain-lain, sehingga perlu dilakukan kajian mengenai pemanfaatannya sebagai antifungi pada tanaman. Oleh karena itu, penelitian ini dilakukan dengan tujuan untuk menentukan konsentrasi optimum ekstrak rimpang lempuyang wangi (Zingiber aromaticum Val.) dalam menghambat pertumbuhan cendawan Pythium sp. dan menentukan persentase aktivitas antifungi optimum dari ekstrak lempuyang wangi (Z. aromaticum Val.). Hasil penelitian menunjukkan bahwa konsentrasi optimum dari ekstrak lempuyang wangi dalam menghambat pertumbuhan cendawan Pythium sp. adalah $50 \%$. Persentase aktivitas antifungi optimum dari ekstrak lempuyang wangi sebesar $51,9725 \%$.
\end{abstract}

Kata Kunci: Lempuyang Wangi, Zingiber aromaticum Val., Pythium sp., Ekstrak Etanol, Biofungisida, Aktivitas Antifungi

Diterima: 22 Juli 2020, disetujui: 20 Januari 2021

\section{Pendahuluan}

Cendawan Pythium sp. merupakan cendawan yang bersifat patogen bagi tanaman. Cendawan tersebut menyebabkan penyakit pada benih berbagai macam tumbuhan (Octriana, 2011). Semangka, mentimun, dan pisang adalah beberapa contoh tanaman yang sering terkena penyakit rebah kecambah yang disebabkan oleh cendawan tersebut. Penyakit ini sering menimbulkan kerugian pada tanaman. Cendawan tersebut dapat menyebabkan kematian pada bibit tanaman yang baru ditanam, bahkan dapat menginfeksi 
sistem perakaran dan batang yang belum muncul atau sudah muncul ke permukaan tanah (Agrios, 2005). Cendawan ini memiliki hifa hialin, tidak bersepta, hifa utama berukuran 5-7 $\mu \mathrm{m}$, lebarnya mencapai $10 \mu \mathrm{m}$. Produksi miselium aerial pada cendawan Pythium sp. tergantung dengan medium yang digunakan (Plaats, 1981).

Serangan Pythium sp. dimulai dari dalam tanah melalui ujung akar (akar pokok atau akar lateral), akibatnya tanaman menjadi layu, kulit akar busuk dan basah. Di samping itu, apabila telah menyebar, tunas dan daun bisa menjadi busuk dan coklat (Triwiratno, 2014). Pengendalian yang umum dilakukan oleh para petani adalah dengan menggunakan fungisida kimia sintetik. Namun demikian, penggunaan fungisida sintetik dapat berdampak buruk bagi tanaman itu sendiri, lingkungan di sekitar tanaman tersebut, dan manusia yang mengonsumsi tanaman tersebut. Oleh karena itu, diperlukan pengendalian yang lebih aman dan ramah lingkungan.

Penggunaan fungisida nabati dinilai lebih ramah lingkungan dibandingkan fungisida sintetik. Tumbuhan mengandung banyak senyawa kimia dan digunakan oleh tumbuhan sebagai alat pertahanan dari serangan organisme perusak tanaman (Syauquk, 2015). Salah satu tumbuhan yang berpotensi sebagai antifungi adalah lempuyang wangi (Zingiber aromaticum Val.). Lempuyang merupakan famili Zingiberaceae yang mengandung beberapa senyawa kimia seperti zerumbon, kurkumin, flavonoid, fenol, saponin, dan minyak atsiri. Kadar zerumbon pada lempuyang wangi lebih dari $40 \%$. Zerumbon merupakan sesquiterpen yang berfungsi sebagai agen kemopreventif melawan kanker usus besar dan kanker kulit, sebagai anti proliferasi dan menginduksi apoptosis dan juga memiliki sifat antifungi (Wahyuni et al., 2013).

Perlu dilakukan pengkajian mengenai pemanfaatan tanaman Lempuyang sebagai antifungi pada tanaman. Oleh karena itu, penelitian ini dilakukan untuk menentukan konsentrasi optimum ekstrak rimpang lempuyang wangi (Z. aromaticum Val.) dalam menghambat pertumbuhan cendawan Pythium sp. dan menentukan persentase aktivitas antifungi optimum dari ekstrak lempuyang wangi (Z. aromaticum Val.) dalam menghambat pertumbuhan cendawan Pythium sp.)

\section{Metode Penelitian}

\section{Subkultur Cendawan Pythium sp.}

Isolat cendawan Pythium sp. yang diperoleh dari InaCC LIPI disubkultur pada medium PDA baru dengan cara cendawan Pythium sp. dicuplik dan diletakkan di tengahtengah cawan petri berisi medium PDA kemudian diinkubasi selama 48 jam.

\section{Pembuatan simplisia rimpang lempuyang}

Rimpang lempuyang wangi yang tidak cacat dan segar (tidak dimakan oleh serangga) dicuci bersih dan diiris tipis dengan ketebalan $5 \mathrm{~mm}$, kemudian dioven selama 15 jam pada suhu $60^{\circ} \mathrm{C}$. Rimpang yang telah kering dibuat serbuk dengan blender, kemudian disimpan dalam wadah tertutup dan gelap.

\section{Maserasi rimpang lempuyang wangi (Zingiber aromaticum Val.)}

Sebanyak 300 gram serbuk rimpang lempuyang ditambah $1500 \mathrm{ml}$ pelarut etanol 96\% dimaserasi selama 24 jam. Selanjutnya disaring menggunakan kertas saring hingga diperoleh maseratnya. Maserat lempuyang wangi dimasukkan dalam alat rotary evaporator dan diuapkan selama 6 jam pada suhu $40^{\circ}$ C. Hasil evaporasi ditampung dalam cawan porselen kemudian dilanjutkan dengan menggunakan waterbath dan diuapkan kembali pada suhu $60^{\circ} \mathrm{C}$ selama 6 jam. Ekstrak kental yang diperoleh diletakkan pada cawan petri dan ditutup rapat dengan alumunium foil dan disimpan pada suhu $4^{\circ} \mathrm{C}$. Hasil rendemen dari suatu ekstrak dihitung menggunakan rumus berikut (Dewi, 2016).

$$
\text { Rendemen }=\frac{\text { bobot ekstrak kental }}{\text { bobot simplisia }} \times 100 \%
$$

\section{Uji Aktivitas Antifungi}

Ekstrak lempuyang wangi masingmasing dibuat konsentrasi $0 \%, 40 \%, 50 \%$, $60 \%$ dan $70 \%$. Masing-masing konsentrasi ekstrak lempuyang wangi sebanyak $1 \mathrm{ml}$ dicampur dengan medium PDA sebanyak $5 \mathrm{ml}$ hingga memadat pada cawan petri. Selanjutnya diberi cuplikan cendawan Pythium sp. di atas 
medium tersebut. Sebagai kontrol positif digunakan fungisida sintetik Antracol dengan konsentrasi $0,03 \mathrm{~g} / 10 \mathrm{ml}$ PDA (\% b/v) dan kontrol negatif yaitu konsentrasi ekstrak 0\% dibuat dengan cara medium PDA dicampur dengan akuades steril $1 \mathrm{~mL}$ tanpa penambahan ekstrak. Pengamatan penghambatan pertumbuhan Pythium sp. dilakukan dengan cara mengamati diameter dari miselium yang terbentuk di sekitar cuplikan cendawan Pythium sp. sampai miselium pada kontrol negatif memenuhi cawan petri (7 hari).

Menurut Nefzi et al. (2016), persentase aktivitas antifungi dihitung menggunakan rumus berikut.

$$
\mathrm{P}=\frac{d c-d t}{d c} \times 100 \%
$$

Keterangan:

$\mathrm{dc}=$ diameter miselia cendawan pada kontrol negatif

$\mathrm{dt}=$ diameter miselia cendawan pada perlakuan

Nilai dari persentase aktivitas antifungi ini dapat dikelompokkan dalam beberapa tingkat aktivitas. Klasifikasi aktivitas antifungi ditunjukkan pada Tabel 1. Data pada penelitian ini dianalisis menggunakan uji ANOVA, dan apabila terdapat beda nyata dilanjutkan dengan uji DMRT (Duncan's Multiple Range Test).

Tabel 1. Klasifikasi tingkat aktivitas antifungi (Novriyanti et al., 2010).

\begin{tabular}{ll}
\hline \hline Aktivitas Antifungi & Tingkat Aktivitas \\
\hline \hline $\mathrm{P}>75 \%$ & Sangat Kuat \\
$50 \%<\mathrm{P} \leq 75 \%$ & Kuat \\
$25 \%<\mathrm{P} \leq 50 \%$ & Sedang \\
$0<\mathrm{P} \leq 25 \%$ & Lemah \\
0 & Tidak aktif \\
\hline \hline
\end{tabular}

\section{Hasil dan Pembahasan}

Berat awal serbuk rimpang lempuyang wangi yang digunakan pada penelitian ini adalah 300 gr. Setelah proses ekstraksi diperoleh berat akhir sebanyak 25,56 gr. Berdasarkan hasil perhitungan rendemen, dapat kita ketahui bahwa rendemen dari ekstrak etanol $96 \%$ rimpang lempuyang wangi (Z. aromaticum Val.) adalah 8,52\%. Karakteristik dari ekstrak etanol $96 \%$ dari rimpang lempuyang wangi yaitu teksturnya kental menyerupai pasta dan berwarna coklat tua.

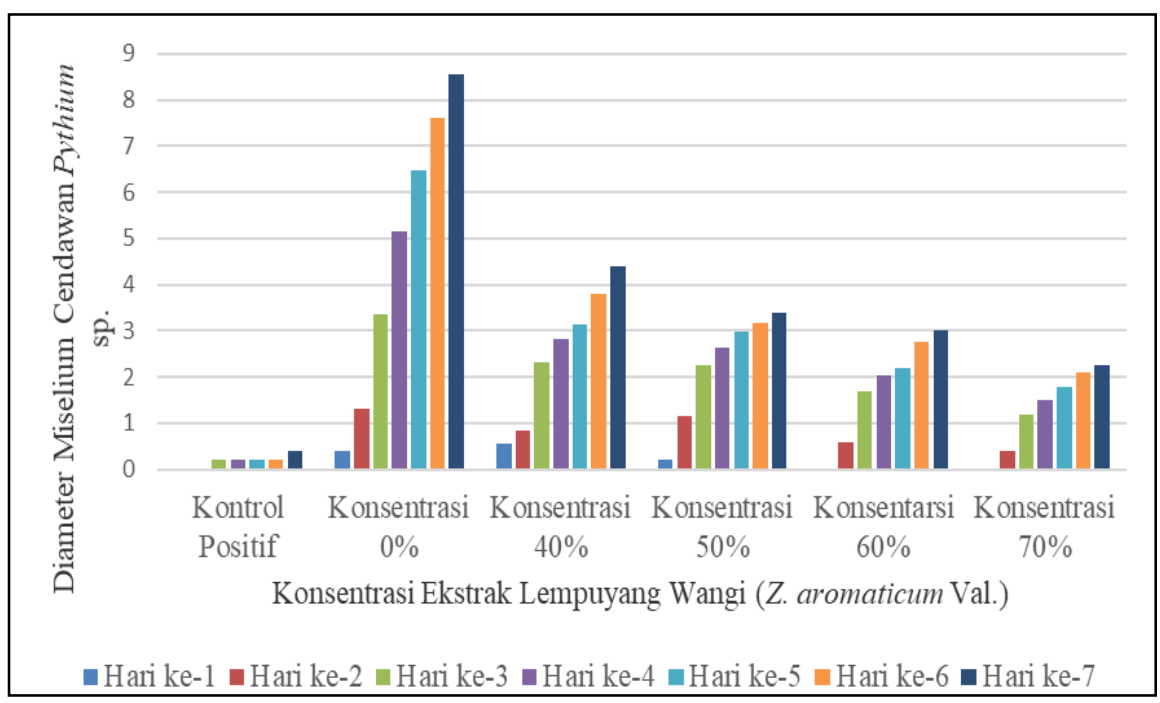

Gambar 1. Pengaruh pemberian ekstrak etanol $96 \%$ rimpang lempuyang wangi (Z. aromaticumVal.) terhadap pertumbuhan isolat cendawan Pythium sp.

Gambar 1 menunjukkan pertumbuhan rata-rata diameter miselium cendawan Pythium sp. yang terbentuk pada media di hari pertama sampai hari terakhir pengamatan. Pada Gambar 1 tampak perbedaan antara diameter miselium cendawan yang tumbuh setiap harinya. 
Diameter miselium cendawan Pythium sp. terbesar pada pengamatan hari ke-7 adalah pada konsentrasi ekstrak 0\% yaitu sebesar 8,6 $\mathrm{cm}$. Diameter miselium cendawan Pythium sp. terkecil pada pengamatan hari ke-7 adalah pada konsentrasi ekstrak $70 \%$ yaitu $2,3 \mathrm{~cm}$. Hal tersebut karena dimungkinkan karena pengaruh konsentrasi ekstrak yang ditambahkan. Semakin tinggi konsentrasi ekstrak lempuyang wangi yang ditambahkan, maka aktivitas antifungi semakin tinggi. Dengan demikian pertumbuhan cendawan Pythium sp. akan terganggu dan diameternya tidak bertambah besar.

Salah satu senyawa yang terdapat pada ekstrak rimpang lempuyang wangi yaitu zerumbon (golongan terpenoid). Senyawa ini diduga dapat berfungsi sebagai zat antifungi terhadap cendawan Pythium sp. Mekanisme senyawa terpenoid dalam menghambat pertumbuhan cendawan menurut Gersehnzon (2007), yaitu senyawa dapat menyebabkan terjadinya perubahan permeabilitas membran. Terpenoid berperan sebagai pelarut yang bisa memasukkan metabolit sekunder lainnya ke dalam membran sel. Natta et al. (2008) mengungkapkan bahwa adanya sifat hidrofobik pada senyawa metabolit jenis terpenoid menyebabkan kerusakan membran, koagulasi sel dan terjadinya gangguan proton pada sel cendawan.

Selain terpenoid, senyawa lain yang berperan sebagai antifungi pada ekstrak lempuyang wangi adalah flavonoid dan alkaloid. Mekanisme flavonoid dalam menghambat pertumbuhan cendawan yaitu dengan berikatan dengan enzim ekstraseluler dan protein terlarut (Al-Bayati, 2008). Menurut Tsuchiya et al. (1996), senyawa flavonoid bisa merusak membran sel pada cendawan. Setelah membran sel rusak, cendawan tidak akan bisa berkembang biak lagi. Mekanisme penghambatan metabolit sekunder jenis alkaloid menurut Doughari (2008), yaitu dengan menyisip di antara dinding sel atau menyisip pada DNA cendawan, sehingga akan mencegah DNA bereplikasi dan pertumbuhan cendawan akan terganggu.

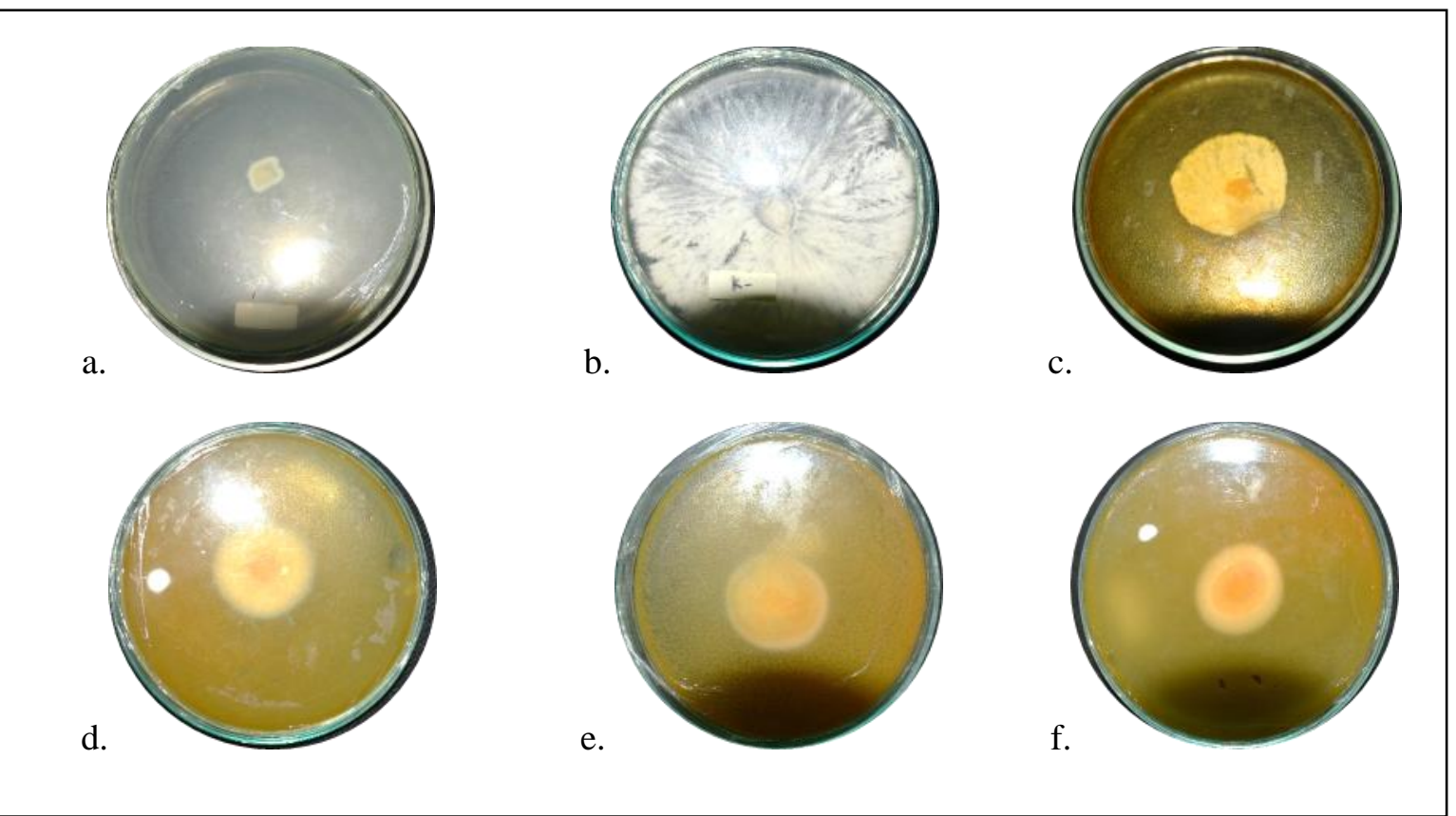

Gambar 2. Pengaruh pemberian ekstrak etanol $96 \%$ rimpang lempuyang wangi (Z. aromaticumVal.) terhadap pertumbuhan isolat cendawan Pythium sp.: a) Kontrol positif; b) Konsentrasi 0\%; c) Konsentrasi $40 \%$; d) Konsentrasi 50\%; e) Konsentrasi 60\%; f) Konsentrasi $70 \%$.

Gambar 2 menunjukkan diameter miselium cendawan Pythium sp. yang terbentuk pada berbagai macam perlakuan. Pada masing-masing konsentrasi terdapat perbedaan ukuran diameter miselium cendawan yang terbentuk. Semakin besar konsentrasi ekstrak rimpang lempuyang wangi yang digunakan, maka semakin kecil diameter miselium cendawan Pythium sp. yang terbentuk. 

Tabel 1. Rerata panjang diameter miselium cendawan Pythium sp. pada Hari ke-7

\begin{tabular}{ll}
\hline \hline Perlakuan & Rerata Panjang Diameter $(\mathbf{c m})$ \\
\hline \hline Kontrol positif & $0,4^{\mathrm{a}}$ \\
Konsentrasi 0\% & $8,55^{\mathrm{f}}$ \\
Konsentrasi 40\% & $4,4^{\mathrm{e}}$ \\
Konsentrasi 50\% & $3,4^{\mathrm{d}}$ \\
Konsentrasi 60\% & $3^{\mathrm{c}}$ \\
Konsentrasi 70\% & $2,25^{\mathrm{b}}$ \\
\hline \hline
\end{tabular}

Keterangan: perbedaan huruf superskrip menunjukkan beda nyata berdasarkan analisis menggunakan DMRT

Tabel 2. Persentase aktivitas penghambatan dan tingkat aktivitas

\begin{tabular}{lll}
\hline \hline Perlakuan & Persentase Aktivitas Penghambatan $(\%)$ & Tingkat Aktivitas \\
\hline \hline Kontrol positif & $95,7375^{\mathrm{f}}$ & Sangat kuat \\
Konsentrasi 0\% & $0,8540^{\mathrm{a}}$ & Lemah \\
Konsentrasi $40 \%$ & $45,4725^{\mathrm{b}}$ & Sedang \\
Konsentrasi $50 \%$ & $51,9725^{\mathrm{c}}$ & Kuat \\
Konsentrasi $60 \%$ & $62,4725^{\mathrm{d}}$ & Kuat \\
Konsentrasi $70 \%$ & $71,9075^{\mathrm{e}}$ & Kuat \\
\hline
\end{tabular}

Keterangan: perbedaan huruf superskrip menunjukkan beda nyata berdasarkan analisis menggunakan DMRT

Data pada Tabel 1 dan 2 menunjukkan bahwa variasi konsentrasi ekstrak lempuyang wangi yang ditambahkan berpengaruh terhadap panjang diameter miselium dan tingkat aktivitas penghambatan cendawan. Persentase penghambatan sejalan dengan aktivitas penghambatannya. Semakin besar angka persentase penghambatan, maka semakin kuat pula tingkat aktivitas penghambatannya, begitu pula sebaliknya. Kandungan senyawa antifungi yang semakin meningkat menyebabkan pertumbuhan cendawan semakin tertekan. Selain itu, semakin tinggi kandungan antifunginya, maka aktivitas penghambatan pertumbuhan cendawan akan semakin kuat.

Hasil analisis dengan uji Duncan menunjukkan bahwa semua konsentrasi memiliki persentase aktivitas penghambatan yang berbeda nyata satu sama lain. Namun, berdasarkan penggolongan aktivitas antifungi, perlakuan konsentrasi 50\%, 60\%, dan $70 \%$ memiliki tingkat aktivitas yang sama yaitu kuat. Hal ini menunjukkan bahwa berdasarkan hasil dari penelitian ini, ekstrak etanol lempuyang wangi konsentrasi 50\% merupakan konsentrasi terbaik dalam menghambat pertumbuhan cendawan Pythium sp. dengan persentase aktivitas penghambatan $51,97 \%$.
Konsentrasi $50 \%$ merupakan konsentrasi terendah yang sudah dapat menghambat pertumbuhan cendawan Pythium sp. dengan tingkat penghambatan yang kuat. Dengan demikian, ekstrak etanol $96 \%$ dari rimpang lempuyang wangi terbukti dapat menekan pertumbuhan cendawan Pythium sp. dan berpotensi untuk dijadikan sebagai biofungisida.

\section{Simpulan}

Konsentrasi optimum ekstrak etanol 96\% rimpang lempuyang wangi (Zingiber aromaticum Val.) dalam menghambat pertumbuhan cendawan Pythium sp. adalah $50 \%$ yaitu dengan persentase aktivitas antifungi optimum dalam menghambat pertumbuhan cendawan Pythium sp. adalah $51,97 \%$.

\section{Daftar Pustaka}

Agrios, G. N. (2005). Plant Pathology. 5th ed. California: Elsevier Academic Press.

Al-Bayati, F. A. dan H. F. Al-Mola. (2008). Antibacterial And Antifungal Activities 
Of Different Parts Of Triculus terrestris L. Growing In Iraq. Journal Zheijang Univ Sci B Vol. 9 (2) : 154-159.

Darmawan, ujang W dan Illa Anggraeni. (2012). Pengaruh Ekstrak Rimpang Kunyit (Curcuma domestica Val.), Lengkuas (Languas galanga L.) Stunz, dan Kencur (Kaempferia galanga L.) Terhadap Pythium sp. Secara In-Vitro. Jurnal Penelitian Hutan Tanaman Vol 9 No 3 (135-140).

Doughari, J. H. Dan J. S. Obidah. (2008). In-vitro Antifungal Activity Of Stem Bark Extract Of Leptadenia lancifolia. IJIB Vol 3 (2) : 111-117.

Gershenzon, J. Dan N. Dudareva. (2007). The Function of Terpen Natural Products In The Natural World. Nature Chemical Biology 5 (3) : 408-414.

More, Y. D., R. M. Gade \& A. V. Shitole. (2017). Evaluation of Antifungal Activities of Extracts of Aegle marmelos, Syzygium cumini and Pongamia pinnata against Pythium debaryanum. Indian Journal of Pharmaceutical Sciences 79(3): 377-384.

Natta, L., Orapin., Krittika dan Pantip. (2008). Uji Antijamur Kombucha Coffee Terhadap Candida albicans dan Tricophyton mentagrophytes. Jurnal Penelitian Sains dan Teknologi Vol. 10 (1) : 10-17.

Novriyanti, E, Santosa, E, Syafii, W, Turjaman, M, \& Sitepu, IR., (2010), 'Antifungal Activity of Wood Extract of Aquilaria crassna Pierre ex Lecomte Against Agarwood-Inducing Fungi, Fusarium solani', Journal od Foresty Research, $7(2)$ : 155-165.

Octriana, Liza. (2011). Potensi Agen Hayati dalam Menghambat Pertumbuhan Pythium sp. secara In Vitro. Buletin Plasma Nutfah Vol 17 No 2.

Plaats-Niterink, Van der. (1981). Monograph Of The Genus Pythium. Stud. Mycol. 21:1242.

Syauquk, Ayu 2015. https://tnalaspurwo.org/?=Pestisida+naba ti. Pestisida Nabati. Diakses pada $28 \mathrm{Mei}$ 2019.

Triwiratno, Anang. .http://balitjestro.litbang.pertanian.go.id. Rebah Kecambah pada Perbenihan Jeruk. Diakses pada tanggal 29 Mei 2019.

Tsuchiya, H., M. Sato, T. Miyazaki, S. Fujiwara, S. Tanigaki, M. Ohyama, T. Tanaka, I. Takase dan M. Linuma. (1996). Comparative Study On The Antibacterial Activity Of Phytochemical Flavanones Againts Methicilin-resistant Staphylococcus aureus. Journal Ethnopharmacol. $50: 27-34$.

Wahyuni, Sri, Nurliani Bermawie, Natalini Nova Kristina. (2013). Karakteristik Morfologi, Potensi Produksi Dan Komponen Utama Rimpang Sembilan Nomor Lempuyang Wangi. Jurnal Littri 19 (3). 